\title{
Cost-effectiveness of Antipsychotics in Treatment of Schizophrenia Patients admitted to a Secondary Hospital
}

\section{Yuni Andriani*, Frisca Nindy Septiani, Defirson,}

Sekolah Tinggi Ilmu Kesehatan Harapan Ibu Jambi

\begin{abstract}
Schizophrenia is a chronic disease that requires relatively high treatment cost. Several studies have found that atypical antipsychotics are more effective compared to typical antipsychotics. As a result, the duration of treatment and the patients' length of hospital stay will be shorter which ultimately reduce the overall treatment costs. Therefore, it is necessary to conduct a cost-effectiveness analysis (CEA) of the two classes of antipsychotic drugs in the treatment of schizophrenia inpatients admitted to Jambi Province Hospital period 2013-2016. This retrospective cohort study was undertaken to analyze cost-effectiveness of the antipsychotic drugs provided to patients with schizophrenia $(n=910)$ admitted to Jambi Province Hospital from the perspective of a healthcare provider. using purposive sampling technique. Characteristics of the patients, antipsychotic drugs usage, costs consumed, and treatment outcome were extracted from the hospital databases and descriptively analyzed. Average Cost-effectiveness Ratios (ACERs) and Incremental Cost-effectiveness Ratio (ICER) of the two type of antipsychotics were analyzed.It was found that the ACER of: the typical antipsychotic group, IDR 142,789.25; atypical antipsychotics, IDR 163,045.50 which indicates that the typical ACER antipsychotic drug was lower than those of atypical antipsychotics based on the length of stay (LOS) of patients in the Psychiatric Intensive Care Unit (PICU) room. Whereas based on the PANSS-EC score of the patient, the total ACER value of the typical antipsychotic group was IDR1,189,910.42 and in atypical antipsychotics was IDR. 572,089.47. Atypical antipsychotics are more cost-effective than typical antipsychotics.
\end{abstract}

Keywords: Schizophrenia, Antipsychotic drugs, Cost Effectiveness

\begin{abstract}
Abstrak. Skizofrenia adalah penyakit kronis yang membutuhkan biaya perawatan yang relatif tinggi. Beberapa penelitian telah menemukan bahwa antipsikotik atipikal lebih efektif dibandingkan dengan antipsikotik tipikal, sehingga durasi perawatan dan lama tinggal di rumah sakit akan lebih pendek yang pada akhirnya mengurangi keseluruhan biaya perawatan. Berdasarkan hal tersebut perlu dilakukan analisis efektivitas biaya (CEA) dari dua kelas obat antipsikotik dalam pengobatan pasien rawat inap skizofrenia yang dirawat di Rumah Sakit Provinsi Jambi periode 2013-2016. Studi kohort retrospektif ini dilakukan untuk menganalisis efektivitas biaya obat antipsikotik yang diberikan kepada pasien dengan skizofrenia $(n=910)$ dirawat di Rumah Sakit Provinsi Jambi dari perspektif penyedia layanan kesehatan. menggunakan teknik purposive sampling. Karakteristik pasien, penggunaan obat antipsikotik,
\end{abstract}

\footnotetext{
*Corresponding author at: Sekolah Tinggi Ilmu Kesehatan Harapan Ibu Jambi

E-mail address: yuni23_fmasi@yahoo.com
} 
biaya yang dikonsumsi, dan hasil pengobatan diperoleh dari data yang dimiliki rumah sakit dan dianalisis secara deskriptif. Average Cost-effectiveness Ratios (ACERs) dan Incremental Costeffectiveness Ratio (ICER) dari kedua jenis antipsikotik dianalisis. Ditemukan bahwa ACER dari: kelompok antipsikotik tipikal, Rp. 142.789,25; antipsikotik-atipikal, Rp.163.045,50 yang menunjukkan bahwa obat antipsikotik ACER khas lebih rendah daripada antipsikotik atipikal berdasarkan lama tinggal (LOS) pasien di ruang Unit Perawatan Intensif Psikiatri (PICU). Sedangkan berdasarkan skor PANSS-EC pasien, total nilai ACER dari kelompok antipsikotik tipikal adalah Rp1.189.910,42 dan pada antipsikotik atipikal adalah Rp. 572.089,47. Hasil menunjukan bahwa antipsikotik atipikal lebih hemat biaya daripada antipsikotik tipikal.

Kata kunci: Skizofrenia, obat antipsikotik, Efektivitas Biaya

Received 25 October 2019| Revised 30 December 2019| Accepted 31 December 2019

\section{Introduction}

Cost-effectiveness analysis is necessary to be carried out to make decisions on drug selection in terms of benefits and costs [2]. Pharmacoeconomic analysis such as CEA can be used to determine whether a drug is sufficient to be offered and used in health services [3]. Cost-effective drug selection allows the rational use of health care funds so that the quality and scope of services can be further enhanced [4]. In 2013, O’Day, Rajagopalan, Meyer, Pikalov, \& Loebel conducted research on costeffectiveness of atypical antipsychotics and found that the cost-effectiveness of lurasidone was better than that of generic atypical antipsychotics (Risperidoneeridone, ziprasidone, and olanzapine) and atypical branded antipsychotics (extended-release quetiapine and aripiprazole). Other study suggested that atypical antipsychotics were more cost-effective compared to first-generation of antipsychotics (Haloperidolperidol). Additionally, in 2015, Adriana et al concluded that atypical antipsychotics were more cost-effective than typical antipsychotics [7].

Most of the previous studies carried out generally focused on comparing two antipsychotic therapies by measuring LOS as the effectiveness measure of schizophrenia treatment. For this reason, an assessment of PANSS-EC (Positive and Negative Syndrome Scale Component) is needed to measure the effectiveness of a drug to treat schizophrenia. PANSS is a rating scale of positive, negative, and general psychopathology in schizophrenia patients that can be used to indicate psychotic symptoms related to treatment targets and accurately and validly predict the patient's response to the treatment given. PANSS-EC is an indicator of restless rowdy patients also used to quickly treat restless rowdy patients [8]. Based on the above facts, this study analyzed the cost-effectiveness of antipsychotics in schizophrenia patients by measuring PANSS-EC scores as their treatment effectiveness. 


\section{Methods}

\subsection{Place / Location and Time of Research}

This research was conducted at the Regional Mental Hospital of the Province of Jambi medical record section from November 2017 to March 2018.

\subsection{Research Design}

This research is a retrospective cohort study. The researcher used a purposive sampling technique.

\subsection{Population and Sample of the Study}

The population in this study is medical records of in-patients with schizophrenia who used antipsychotics in the installation of the Jambi Provincial Hospital. The research sample was medical records of the in-patients with schizophrenia admitted to the hospital period 2013-2016 with inclusion criteria: medical records of patients registered in the inpatient installation of Jambi Provincial Hospital in 2013-2016, diagnosed with schizophrenia, taking typical antipsychotic drugs (Haloperidolperidol, Chlorpromazine, and fluphenazine-decanoate) and / or atypical (Risperidoneeridone, olanzapine and Clozapineapine) until cured, complete and clearly read patient medical records. The exclusion criteria were medical records of the schizophrenia patients with complications, patients who discharged with their own, patients who experienced recurrence after being declared cured.

\subsection{Data Sources}

Characteristics of the schizophrenia patients, antipsychotic drugs provided, costs consumed, and their treatment outcome period 2013-2016 were extracted from the hospital databases. All of these data were organized in and descriptively analyzed. Average Cost-effectiveness Ratios (ACERs) and Incremental Cost-effectiveness Ratio (ICER) of the two type of antipsychotics were analyzed

\subsection{Research Procedures}

\subsubsection{Sampling}

Sampling was done by searching the medical records of schizophrenia patients hospitalized period 2013-2016. The data extracted were the patients' initial name, medical record number, age, gender, LOS, antipsychotics provided, antipsychotics costs; average patient PANSS-EC score; costs of doctor's intervention; maintenance costs during the PICU room.

\subsubsection{Data processing}


Editing was performed by re-checking the completeness of the data obtained from the medical records in the in-patient installation of Jambi Provincial Hospital. All of the required data were organized and entered into the EXCEL program.

\subsection{Data Analysis}

Cost-effectiveness analysis was undertaken by calculating the cost-effectiveness ratio (CER) and incremental cost-effectiveness ratio (ICER). The data were tabulated based on the type of data collected in the medical record room of the Jambi Province Regional Mental Hospital including the costs of antipsychotic drugs provided to the patients, physicians' costs, maintenance fees in the PICU room, the length of treatment of the schizophrenia patients while in the PICU room, the patients' PANSS-EC scores. Cost-effectiveness analysis of the schizophrenia treatment with the antipsychotics was undertaken effectiveness, ACER, and ICER using the following formula:

$$
\begin{aligned}
& \text { Effectiveness }=\frac{\text { PANSS Score } \leq \text { average }}{\text { total sample }} 100 \% \\
& \text { ACER }=\frac{\text { costs of antipsychotics }}{- \text { effectiveness of antipsychotic }} \\
& \text { ICER }=\frac{\text { Costs of Drug A -Costs of Drug B }}{\text { Efectivity of drug A-effectivity of Drugs B }}
\end{aligned}
$$

\section{Results and Discussion}

Based on the results of a preliminary study at the Jambi Provincial Mental Hospital, number of the schizophrenia patients during period 2013 to 2016 reached about hundreds to thousands of patients each year, with the highest number of patients in 2014 totaling 3,197 patients with temporary schizophrenia, schizotypal disorders, and acute psychotic disorders. Of the 3,197 patients admitted during the period, only 916 patients met the inclusion criteria.

\subsection{Results}

\subsubsection{Overview of research subjects}

The results of the study in the inpatient installation of the Jambi Provincial Hospital indicated that there were more male patients (68.67\%) compared to female which only reached $31.33 \%$. Based on age range, most of the patients were in the age range of 17-25 years and the lowest was in the age range of higher than 65 years old. Then based on the level of education, most patients were with elementary education level and the lowest was the D2 education level.[9] Data can be seen in Table 1. 
Table 1. Characteristics of the Patients with Schizoprenia (n=916)

\begin{tabular}{lll}
\hline Characteristics & Total & Percentage $(\%)$ \\
\hline Gender: & & \\
\hline Male & 629 & 68.67 \\
Female & 287 & 31.33 \\
\hline Age (years): & & \\
\hline $17-25$ & 352 & 38.43 \\
$26-35$ & 308 & 33.62 \\
$36-45$ & 161 & 17.58 \\
$46-55$ & 73 & 7.97 \\
$56-65$ & 16 & 1.75 \\
$\geq 65$ & 6 & 0.655 \\
\hline
\end{tabular}

\begin{tabular}{lll}
\hline Level of education & & \\
\hline Uneducated & 227 & 24.78 \\
SLB & 2 & 0.22 \\
Elementary & 306 & 33.41 \\
Junior High School & 168 & 18.34 \\
Senior High School & 198 & 21.62 \\
Diploma 2 & 1 & 0.11 \\
Diploma 3 & 7 & 0.76 \\
Bachelor & 7 & 0.76 \\
\hline
\end{tabular}

\subsubsection{Utilization and Costs of the Typical Antipsychotic Drugs Provided to Patients with} Schizoprenia

Utilization of antipsychotic drugs based on class therapy provided to patients with schizophrenia admitted to the installation of the Jambi Provincial Hospital period 2013 to 2016 is shown in Table 2. Most (52.29\%) of the patients with schizophrenia were provided typical antipsychotics.

Table 2. Utilization of Antipsychotic Drugs based on Class Therapy

\begin{tabular}{lll}
\hline Class Therapy & Total & Percentage \\
\hline Typical & 479 & 52.29 \\
Atypical & 437 & 47.71 \\
\hline
\end{tabular}

Typical antipsychotic usage cost data obtained an average of IDR 19,773 where the highest cost is in combination with fluphenazine decanoate because its dosage form is ampoules with a quite expensive 
cost (IDR 72,500/ampoule). Then the cost of hospitalization in the PICU room has obtained an average of RPIDR 522,634.08 per treatment period. While the cost of the doctor's intervention was obtained an average of IDR.28,750. So that a total average cost of IDR 571.157 (table 3).

Table 3. Costs (in IDR ) of Typical Antipsychotics Provided to Patients with Schizoprenia

\begin{tabular}{|c|c|c|c|c|c|c|}
\hline Class & & Antipsychotics & $\begin{array}{l}\text { Average } \\
\text { Cost }\end{array}$ & $\begin{array}{l}\text { Cost in PICU } \\
\text { room }\end{array}$ & $\begin{array}{l}\text { Average Cost of } \\
\text { Doctor's } \\
\text { intervention }\end{array}$ & $\begin{array}{l}\text { Average } \\
\text { Total Cost }\end{array}$ \\
\hline \multirow[t]{2}{*}{ Typical } & & Haloperidol & 1.748 & $524.347,83$ & 25.000 & 551.096 \\
\hline & & Chlorpromazine & 421 & 505.000 & 25.000 & 530.421 \\
\hline \multirow[t]{2}{*}{$\begin{array}{l}\text { Typical } \\
\text { Typical }\end{array}$} & + & $\begin{array}{l}\text { Haloperidol } \\
\text { chlorpromazine }\end{array}$ & 2.208 & 529.859 & 25.000 & 557.067 \\
\hline & & $\begin{array}{l}\text { Haloperidol + } \\
\text { chlorpromazine } \\
+ \text { Fluphenazine }\end{array}$ & 74.714 & $531.329,48$ & 40.000 & 646.043 \\
\hline Average & & & 19.773 & $522.634,08$ & 28.750 & 571.157 \\
\hline
\end{tabular}

Antipsychotics consumed by the patients can affect their LOS in the PICU room where from 479 patients using typical antipsychotics, the average LOS for patients in the PICU room was 4 days (table 4).

Table 4. The average LOS of PICU Room with Typical Anti Antipsychotic $\underline{s}$

Class Antipsychotic

\begin{tabular}{lll}
\hline Typical & Haloperidol & 4.4 \\
& Chlorpromazine & 4.2 \\
\cline { 2 - 3 } Typical & & \\
+ Typical & Haloperidol + chlorpromazine & 4 \\
& Haloperidol + chlorpromazine + fluphenazine & 4.4 \\
\hline Average & & 4.25 \\
\hline
\end{tabular}

In addition to being assessed based on LOS, the effectiveness of therapy can also be assessed by PANSS-EC (Positive and Negative Syndrome Scale-Excited Components). In patients with typical antipsychotics, the average PANSS-EC score is 22. Data can be seen in Table 5 below:

Table 5. Average PANSS-EC score of Typical Antipsychotics

\begin{tabular}{lll}
\hline \multirow{2}{*}{ Class } & Antipsychotic & $\begin{array}{l}\text { Average } \\
\text { PANSS score }\end{array}$ \\
\hline \multirow{2}{*}{ Typical } & Haloperidol & 23,39 \\
& Chlorpromazine & 22,71 \\
\cline { 2 - 3 } Typical + Typical & haloperidol + chlorpromazine & 21,5
\end{tabular}


haloperidol + chlorpromazine + fluphenazine 20

$\begin{array}{ll}\text { Average } & 22\end{array}$

\subsubsection{Costs of Atypical Antipsychotic Drugs Provided to Patients with Schizoprenia}

Calculation of costs of atypical antipsychotic drugs provided to patients with schizophrenia is listed in Table 6. Average cost of antipsychotic drugs was IDR 12,052, the average cost of treatment in the PICU room was IDR 289,039.25, and the average cost of the doctor's intervention was IDR 25,000. Thus, the average total costs for the treatment of the patients was IDR 326,091.

Table 6. Costs Atypical Antipsychotics Provided to Patients with Schizoprenia

\begin{tabular}{llllll}
\hline Class & $\begin{array}{l}\text { Drug } \\
\text { name }\end{array}$ & $\begin{array}{l}\text { Average } \\
\text { cost }\end{array}$ & $\begin{array}{l}\text { Average of Care } \\
\text { cost }\end{array}$ & $\begin{array}{l}\text { Average Cost of } \\
\text { Doctor's } \\
\text { interventions }\end{array}$ & $\begin{array}{l}\text { Average of the } \\
\text { total cost }\end{array}$ \\
\hline Atypical & $\begin{array}{l}\text { Risperido } \\
\text { ne }\end{array}$ & 14.182 & 293.425 & 25.000 & 332.607 \\
& $\begin{array}{l}\text { Olanzapin } \\
\text { e }\end{array}$ & 11.248 & 281.194 & 25.000 & 317.442 \\
& \begin{tabular}{l} 
Clozapine \\
\cline { 2 - 6 } Atypical
\end{tabular}$+\begin{array}{l}\text { Risperido } \\
\text { ne }+1.362\end{array}$ & 290.769 & 25.000 & 320.131 \\
\hline Atypical & $\begin{array}{l}\text { Clozapine } \\
\text { Average }\end{array}$ & 12.415 & 290.769 & 25.000 & 334.184 \\
\hline
\end{tabular}

Table 7. Average LOS of the Patients Provided Atypical Drugs in PICU Room

Class

Antipsychotic

Average LOS in PICU room

\begin{tabular}{lll}
\hline Atypical & Risperidone & 2.4 \\
& Olanzapine & 2.3 \\
& Clozapine & 2.4 \\
\cline { 2 - 3 } Atypical + Atypical & Risperidone + Clozapine & 2 \\
\hline Average & & 2.275 \\
\hline
\end{tabular}

Table 8. Average PANSS-EC Score of Atypical

$\begin{array}{lll}\text { Class Antipsychotic Average } & \text { An }\end{array}$




\begin{tabular}{lll}
\hline & & PANSS Score \\
\hline Atypical & Risperidone & 19.38 \\
& Olanzapine & 19.01 \\
& Clozapine & 19.04 \\
\cline { 2 - 3 } Atypical + Atypical & Risperidone + Clozapine & 18.5 \\
\hline Average & & 18.9825 \\
\hline
\end{tabular}

\subsubsection{Calculation of the Effectiveness of the Cost of Using Antipsychotic Therapy}

Comparison of the use of antipsychotics based on an analysis that is more cost effective based on LOS in the PICU room and PANSS-EC score was atypical antipsychotic. The ACER value of the total cost of atypical antipsychotic use based on LOS in the PICU room was IDR 163,045.5 and atypical antipsychotic IDR 145,789.25 as demonstrated in Table 9. ACER value for the cost of antipsychotics using atypical antipsychotics based on length of stay in the PICU room was IDR 6,026 and atypical antipsychotic IDR 4,943.25 as listed in Table 10.

Table 9. Calculation of Total ACER Based on LOS in the PICU Room

\begin{tabular}{lll}
\hline & Typical & Atypical \\
\hline Total costs (IDR) & 571,157 & 326,091 \\
LOS in PICU room (days) & 4 & 2 \\
\hline ACER & IDR 571,157/4 =142,789.25 & IDR 326.091/2=163,045.5 \\
\hline ICER & No ICER calculation needed & \\
\hline
\end{tabular}

Table 10. Calculation of ACER Antipsychotics Based on LOS in the PICU Room

\begin{tabular}{lll}
\hline & Typical & Atypical \\
\hline CER & & \\
\hline Drugs Costs (IDR) & 19,773 & 12,052 \\
LOS in PICU room (days) & 4 & 2 \\
\hline ACER & IDR 19,773/4 =4,943.25 & IDR 12,052/2 $=6,026$ \\
\hline ICER & No ICER calculation needed \\
\hline
\end{tabular}

ACER value in total costs based on the effectiveness with PANSS-EC score on atypical antipsychotics of IDR 57,089,47 and typical antipsychotics of IDR 1,189,910.42 (11). While the value of ACER based on PANSS-EC scores on atypical antipsychotics was IDR 21.143.86 and typical antipsychotics was IDR 41,193.75 as shown in Table 12.

Table 11. Calculation of Total ACER Based on PANSS-EC Score 


\begin{tabular}{lll}
\hline & Typical & Atypical \\
\hline PANSS Score $\leq$ Average & 232 & 250 \\
Total Sample & 479 & 437 \\
& $232 / 479 \times 100 \%=48.43 \%$ & $250 / 437 \times 100 \%=57.21 \%$ \\
\hline CER & & \\
\hline Total Costs (IDR) & 571,157 & 326,091 \\
Effectiveness & 0.48 & 0.57 \\
\hline ACER & $571,157 / 0.48=1,189,910.42$ & $326,091 / 0.57=572,089.47$ \\
\hline ICER & No ICER calculation needed & \\
\hline
\end{tabular}

Table 12. Calculation of ACER Antipsychotics Based on PANSS-EC Score

\begin{tabular}{lll}
\hline & Typical & Atypical \\
\hline Effectiveness & \multicolumn{2}{l}{} \\
\hline PANSS Score $\leq$ Average & 232 & 250 \\
Total Sample & 479 & 437 \\
& $232 / 479 \times 100 \%=48.43 \%$ & $250 / 437 \times 100 \%=57.21 \%$ \\
\hline CER & \multicolumn{2}{l}{12,052} \\
\hline Cost of antipsychotic (IDR) & 19,773 & 0.57 \\
Effectivity & 0.48 & $12,052 / 0.57=21,143.86$ \\
\hline ACER & $19,773 / 0.48=41,193.75$ & \\
\hline ICER & No ICER calculation needed \\
\hline
\end{tabular}

Based on the CEA as shown in Table 12, ICER calculation was not necessary because the typical antipsychotic has low effectiveness with high costs, so it did not need to be considered as an alternative, and atypical antipsychotics had high effectiveness with lower costs so it was definitely chosen and not needed ICER calculation. Based on these data it can be concluded that atypical antipsychotics were more cost effective than typical antipsychotics [5], [10]-[13].

\subsection{Discussion}

From the research data in the Jambi Provincial Hospital in 2013-2016, there were a total of 1036 inpatients with schizophrenia admitted to the hospital. One hundred and twenty of them were excluded from the study because 103 of them had not recovered (re-hospitalized), 14 patients were discharged in a condition that had not recovered and 3 patients died. Therefore, 916 of the 1036 patients fulfilled the inclusion criteria in which 479 patients received typical antipsychotics and 437 patients received atypical antipsychotics.

Cost analysis was carried out by recording the costs of antipsychotics per dosage form (tablet/ampoule), treatment costs, and the cost of doctor's interventions. An intervention is said to be 
cost-effective if: it is cheaper and as effective as the comparative intervention; more expensive but also more effective than the comparison (excess costs are proportional to the excess effectiveness provided); cheaper and less effective than the comparison, but the excess price of comparative intervention is not comparable to the excess effectiveness given [1].

Based on the cost-effectiveness analysis, typical antipsychotics are in column $\mathrm{C}$ where costs are higher with lower effectiveness. And atypical antipsychotics are in column $\mathrm{G}$ where lower costs with higher effectiveness. From the observation of the above table, it can be directly concluded that atypical antipsychotics are more cost effective than typical antipsychotics

Table 13. Determination of cost analysis with cost effectiveness

\begin{tabular}{llll}
\hline Cost-effectiveness & Low cost & Same Cost & High cost \\
\hline Low effectiveness & A & B & C \\
Same effectiveness & D & E & Typical \\
High effectiveness & G & H & F \\
\hline
\end{tabular}

Then to strengthen the results, ACER calculations were carried out. The value of ACER obtained from both the cost of antipsychotics and the total cost based on the LOS and PANSS-EC scores showed that the ACER of typical antipsychotic drug was higher than atypical antipsychotics. The present study proved that the atypical antipsychotics are more cost effective compared to typical antipsychotics.

Whereas ICER calculation was considered unnecessary because the typical antipsychotic had low effectiveness with high costs so it does not need to be considered as an alternative, and atypical antipsychotics had high effectiveness with lower costs. so it is definitely chosen and ICER calculations were not needed. Based on these data it can be concluded that atypical antipsychotics were more cost effective than typical antipsychotics.

\section{Conclusion}

From the results of the study, it can be concluded that atypical antipsychotics were more cost-effective than typical antipsychotics based on PANSS-EC scores and LOS of the patients.

\section{References}

[1] Rachmawati, "Analisis Efektivitas Biaya (Cost-Effectiveness Analysis) Penggunaan Antipsikotik (Tipikal dibandingkan dengan Kombinasi Tipikal dan Atipikal) pada Pasien Skizofrenia (Schizophrenia) Rawat Inap di RSUD Dr. Moch Ansari Saleh Banjarmasin," 2010.

[2] T. M. Andayani, Farmakoekonomi Prinsip dan Metodologi. Yogyakarta: Bursa Ilmu, 
2013.

[3] N. Qiyaam, A. Rahem, D. Maria Pia, and Lestiono, "Analisis Efektivitas Biaya ( Cost Effectiveness Analysis ) Penggunaan Amitryptiline Dibandingkan Carbamazepine pada Pasien Nyeri Neuropatik ( Studi Kasus Di Klinik Saraf Rumkital .," vol. 2, no. 2, pp. 47-55, 2015.

[4] Kemenkes RI, Pedoman Penerapan Kajian Farmakoekonomi, vol. 53, no. 9. 2013.

[5] K. O’Day, K. Rajagopalan, K. Meyer, A. Pikalov, and A. Loebel, "Long-term costeffectiveness of atypical antipsychotics in the treatment of adults with schizophrenia in the US," Clin. Outcomes Res., vol. 5, no. 1, pp. 459-470, 2013.

[6] A. J. García-Ruiz, L. Pérez-Costillas, A. C. Montesinos, J. Alcalde, I. Oyagüez, and M. A. Casado, "Cost-effectiveness analysis of antipsychotics in reducing schizophrenia relapses," Health Econ. Rev., vol. 2, no. 1, p. 8, 2012.

[7] Y. Andriani, R. B. Natari, and I. Pratiwi, "Analisis Efektivitas Biaya Obat Tipikal dan Atipikal Antipsikotika pada Pasien Schizophrenia di Rumah Sakit Jiwa Provinsi Jambi Tahun 2012," 2015.

[8] M. Obermeier et al., "Is the PANSS used correctly? A systematic review," BMC Psychiatry, vol. 11, no. 1, p. 113, 2011.

[9] C. Tannenbaum, A. Paquette, S. Hilmer, J. Holroyd-Leduc, and R. Carnahan, "A systematic review of amnestic and non-amnestic mild cognitive impairment induced by anticholinergic, antihistamine, GABAergic and opioid drugs," Drugs and Aging, vol. 29, no. 8, pp. 639-658, 2012.

[10] E. Achilla and P. McCrone, "The cost effectiveness of long-acting/extended-release antipsychotics for the treatment of schizophrenia: A systematic review of economic evaluations," Appl. Health Econ. Health Policy, vol. 11, no. 2, pp. 95-106, 2013.

[11] M. W. H. L. Van Bennekom, H. J. Gijsman, and F. G. Zitman, "Antipsychotic polypharmacy in psychotic disorders: A critical review of neurobiology, efficacy, tolerability and cost effectiveness," J. Psychopharmacol., vol. 27, no. 4, pp. 327-336, 2013.

[12] K. B. Thakkar, M. M. Jain, G. Billa, A. Joshi, and A. A. Khobragade, "A drug utilization study of psychotropic drugs prescribed in the psychiatry outpatient department of a tertiary care hospital," J. Clin. Diagnostic Res., vol. 7, no. 12, pp. 2759-2764, 2013.

[13] Y. R. Sihombing, A. Nasution, and R. Rosidah, "Economic Impact of Counseling on the Management of Patients With Type 2 Diabetes Mellitus Admitted To a Hospital," Asian J. Pharm. Clin. Res., vol. 11, no. 13, p. 94, 2018. 